\title{
Perception of Entrepreneurial Culture in the Islamic Marketing
}

\author{
Berfu ILTER \\ Afyon Kocatepe Universty
}

\begin{abstract}
The Prophet Muhammad is the most important person of the Islamic culture as an individual, honest and ethical. Islamic culture in the prophet's leadership has built up the mentality of trade, entrepreneurship and industry. Thanks to honest entrepreneurs; It is predicted that social transformation and economic empowerment is possible. Entrepreneurial culture, by the society to which they belong develop unique characteristics of entrepreneurs. This study was carried out based on the literature. In the study of Islamic marketing approach, the perception of an entrepreneurial culture should be discussed. As a result, all of the world countries have been fighting against environmental pollution and many economic and political problems recently. Islamic culture has the ability to deal with all these problems experienced owing to the entrepreneurial culture perception in the Islamic marketing concept.
\end{abstract}

Keywords: Islamic Marketing, Entrepreneurship, Culture

\section{Introduction}

Religion consists of commands and judgments conveyed by the Almighty Allah through Prophets to directmankind toward goodness (Ateş, 1997: 7). Religion is one of the most important factors affecting the culture of a society (Marangoz, 2016B: 74).

The religions based on revelations delivered by the Almighty Allah are called Abrahamic religions. These are; Judaism based on the Torah revealed to Moses, Christianity based on the Gospel revealed to Jesus, and Islam based on the Qur'an revealed to Prophet Muhammad. There are also religions established by people who have not received revelation such as Buddhism established by Budda. The first basic principle on which Abrahamic religions agree is that there is an absolute existence with wisdom, power, will which created the universe; "Allah". According to the Qur'an, "Allah is the one and only" (Baqarah, 163). According to the Qur'an,Allah is the only owner of the religion. Religion is a divine and universal institution which is established and protected by Allah. The duties and supremacy of the prophets are due to their duty of conveying the religion revealed by Allah (Atay, 1995: 4-6). In fact, the basis of the teachings of all prophets is the oneness of Allah and only Worship Allah, the Arabic name of which is Islam (Ateş, 1997: 9).

Because of the fact that trading was the major and growing field of business in economic activities in the Arab society especially in Mecca which is the appearance center of Islam, merchants had a voice during that period. Therefore, Islam is a belief which has been structured by Prophet Muhammad (peace be upon him) who was a broad-minded enlightened merchant, and the most prominent leaders of which consisted of merchants (Aydın, 2015: 180).

Islam is a reform arrangement within the frame of the conditions from which it emerged. By "Hilf alFudul" (virtuous agreement) made between Meccan rulers in the previous period, it was aimed to ensure the development of Arabic trade and social relations by making them defined and secure them and in this context to guarantee the human rights (slave-master) around the property relations of that period. Then,this agreement, which was signed by Prophet Muhammad (peace be upon him) when he was 25 years old from notables of Mecca who would later establish Islam, evoked socio-economic requirements which would result in the formation of Islam. That is to say; Islam was later shaped through the socio-economic mind reflected by Hilf alFudul and the way offered by it (Aydın, 2015: 3-4).

Marketing decisions and practices are important in an initiative. According to the statement of Kotler (2003), it is possible to consider marketing decisions and practices as the appearances of initiatives seen by society due to the direct relationships of marketing with consumers. Marketing activities involve all kinds of activities of the initiatives with the market and consumers. Therefore, marketing activities should be accepted as the activities that need to be fulfilled on the basis of considering social requirements and social responsibilities (Ay and Nardal1, 2011: 138). The entrepreneur should make a decision by properly evaluating the economic and environmental consequences of the products and services to be offered in marketing activities and should act sensitively and delicately by considering their effect on other individuals of the society and damages on the environment (Ar1, 2015:249).

The world environmental pollution, reduction of natural resources, global warming, and the everincreasing consumption pose a threat to the present generation and future generations. There is a need for accountable marketing practices for the protection of the environment and the realization of sustainable life and development (Ar1, 2015: 237) 


\section{Islamic Marketing Concept}

Economic activity is usually examined in four parts; Production, exchange, circulation, and consumption. The exchange is seen as a bridge between production and consumption. Circulation is the replacement of goods and money; exchange is the transition of goods and money from the asset of an individual to the asset of another individual. In economy, brokerage and exchange functions between production and consumption are called trade, and those who acquire these businesses as a profession are called merchants (Akşit, 2011: 17). The concept of marketing, in the most general sense, is defined as an exchange (alteration) process (Altunışık et al., 2016: 27).

Islamic marketing concept was shaped on the basis of paving the way for commercial capital by eliminating the tribal sovereignty and the power of usurer's capital. Due to the presence of Kaaba as the house of traditional Arabian gods, there were judgeship regulating the heritage and compensation issues and the council consisting of notables of the tribe for the solution of common problems in the Meccan society where the commercial activity was very intense, and then Hilf al-Fudul (virtuous agreement) was resorted as a result of the lack of these legal institutions. Protection against violations of right and the provision of necessary public assurance for a community life beyond tribal interests especially on the basis of freedom of trade and property safety were aimed in this agreement. The agreement supported slavery, labor rights, and social state. Above all, it was shaping the security sensitivity of Islam which would grow in the next period. The fact that the agreement was deprived of the dominance of balances between tribes over it and an ideological basis that could overcome this was the drawback of the agreement (Aydın, 2015: 169-171).

The main purpose of Islamic perspective related to theeconomic field is the formation of a healthy, dynamic and growth-prone economic model. Islam aims at a rich and prosperous society in which the rights and law are protected and economic justice is assured in accordance with its principles (Erdem, 2015: 14-18).

Rodinson (1976) summarized Islamic marketing concept by saying "The economic activity, profit motive, trade and consequently production for the market are approved by both the Qur'an and Hadith. Remarks praising merchants are found in both of them. It is argued that Prophet Muhammad (peace be upon him) says "a sincere and honest merchant will be among prophets, martyrs and fair people on the day of judgment". According to Hadith Qudsi "trade is defined as an exalted way to gain life. If you generate profit from the trade allowed, then this is jihad. This would be a sadaqah if you use this profit for your family and relatives. A drachma obtained from trading is better than ten drachmas gained in any other way" (Aydın, 2015: 179).

\subsection{Entrepreneur Identity of the Prophet Muhammad (peace be upon him)}

The Prophet was born in a society with a tradition of ignorance in the time of ignorance period. Although the tradition of ignorance had a structure containing violence, aggressiveness, injustice, standing by powerful people, overpowering the oppressed people, tribalism, blood revenge, arrogance, bigotry, and extortion, it had positive behaviors such as generosity, helping relatives, giving food to passengers arriving in Mecca due to the visit to Kaaba, the virtues of which were accepted. The Prophet kept away from all negative behaviors of Ignorance and adopted to implement positive behaviors (Kamac1, 2015: 16).

The Prophet was born in Mecca in 570. His Father Abdullah had died before he was born, and his mother Amina died when he was six years old (576). Abd al-Muttalib took the Prophet who became an orphan at a very young age under his guardianship. He came under the care of his uncle Abu Talib when his grandfather died in 579. After nine years of age, he also participated in trade caravans going to Syria and Yemen with his uncles (Atay et al., 1995:19).

As it was mentioned by Ibn Hisham, Ibn Sa'd and Al-Maqrizi, the Prophet was firstly engaged in sheepherding from early ages to contribute to the budget of his uncle and then made his first commercial trip to Syria with his uncle when he was 12. Then, he made commercial trips to all around the Arabian peninsula, Yemen, East Arabia. The Prophet assumed the responsibility of his family livelihood and gained experience at an early age. With these commercial trips, he had the chance to learn the general structure, languages and dialects of the Arabian peninsula and different cultures. He acquired the nickname "al-Amin" by his principled, fair, patient personality based on giving not on taking especially during his commercial activities. Along with the acquisition of this nickname, Our Prophet became known as "Muhammad al-Amin" in the society since his youth. Muhammad Mustafa (peace be upon him, the birth, childhood and youth of him are replete with the signs of achieving the honor of being aprophet, led an exclusive life in a period of forty years passed until revelation (Cited by: Kamac1, 2015: 19-20). The Messenger of Allah, who assumed the duty of prophecy at the age of forty, took care of every member of the society without making gender or age discrimination as required by theduty of prophecy. He developed a relationship involving love with children and intimacy with youngsters (Erul, 2015: 21-25).

The Prophet was the person who not only conveyed the Qur'an to its addressees but also lived the Qur'an. The Qur'an is the theoretical source of Islam, and the Prophet is the implementation source of religion. However, the Qur'an shaped the Prophet who is the implementation source. The Qur'an is a "book of life" not a 
"taboo book" which is difficult to touch and reach. The Qur'an requires its believer to reach it easily. This reachability is also valid for the lifestyle by the Qur'an. The lifestyle brought by the Qur'an was concretized in the personality of Muhammad (İslamoğlu, 2014: 64-65).

Remember the verses about the Prophethood duty and exemplary personality of the Prophet in the Qur'an:

- "And surely thou hast sublime morals" (Qur'an, The Pen, 4)

- "And as one who invites to Allah's (Grace) by His leave, and as a Lamp spreading Light" (Qur'an, AlAhzáb, 46)

- "to the Believers is he most kind and merciful" (Qur'an, Al-Tauba, 128)

- "Ye have indeed in the Messenger of Allah an excellent exempler for him who hopes in Allah and the Final Day, and who remembers Allah" (Qur'an, Al-Ahzáb.21; Qur'an, Al-Baqarah, 143)

\subsection{Entrepreneurial Culture in Today's Muslim Model}

An entrepreneur is a person who sets up a new business by taking risks and uncertainties in order to achieve profit and growth by collecting the necessary resources to make use of significant opportunities by utilizing (Scarborough, 2014:4). According to Raelin (1999), entrepreneurs guide the entrepreneurial activities in the business world by being affected by the attitudes and behaviors created by their society specific to themselves (Cited by: Şimşek, 2013:115). Culture refers to the way of alife spent by a society along with its all material and spiritual elements. The mutual interaction of societies also provides the mutual interaction of their cultures. The intercommunal cultural interaction takes place within the context of both material and spiritual cultural elements (İrmiş, 2010: 44).

According to Tylor (1971),culture is a complex complement containing other skills and habits such as the information obtained by the person as a member of society, art, morals and traditions. In this context, Güvenç (1984) stated that classification could be made according to different civilizations, religions, political and economic systems and geographic areas that form the world such as eastern culture-western culture, Christian culture-Islamic culture, capitalist culture-socialist culture-democratic culture (cited by: Şişman, 2011: 2-8). Hofstede (2001) defined Turkish culture as collectivist, namely a cultural structure dominated by the "sense of we" instead of "self" in which people determine their interests according to the interests of the society. In this context, the importance of the concept of socially responsible marketing for society should be brought to the forefront in marketing studies by drawing attention to the benefits to the social utility (cited by: Ar1, 2015: 248).

As it was stated by Așkın (2011), Durukan (2006) and Çevik (2006), it is seen that Turkish people tended towards trade and art along with their transition to settled social order, but they moved to fields such as agriculture, livestock, and military when it came to the Ottoman period by moving away from the trade. In the recent times of the Ottoman Empire, entrepreneurs consisted of Jewish, Greek, Italian-origin Turkish citizens who were in closer connection and information exchange with the West after the Industrial Revolution. However, significant efforts were made regarding "making Turkish people businessmen and merchants" and "creating Muslim and Turkish businessmen" in the recent period of the empire and especially in the Union and Progress period (cited by:Marangoz, 2016A: 11-13).

The commercial moral principles that should be obeyed by a Muslim entrepreneur are indicated in Islam. These principles are (Akşit,2011,35-115):

- To be truthful, reliable and honest,

- Not to take an oath while trading,

- To keep your promise and pay the debt at maturity,

- To try to incorporate,

- To get up early in the morning, to start work early,

- Not to delay prayers,

- To be respectful to blessings, not to waste,

- Not to be stingy,

- Not to be greedy,

- Not to get into debt unless becoming helpless,

- Not to pressure the debtor,

- To give employee his due,

- Not to be engaged in black-marketeering,

- Not to be engaged in unfair competition,

- To say goodbye to relatives while going outside to buy goods and to read some surah,

- To seek refuge in Allah while getting into market,

- Not to obtain goods through ways forbidden by religion,

- Not to do usury, not to get involved in usury, 
- To give sadaqah,

- To make things easier while trading,

- To be patient and perseverant, to believe in Allah,

- To be brave and entrepreneurial,

- Not to be arrogant.

The most important problem of today's Muslims is the unreliability. However, Muslims were reliable and trusted. A Muslim, whom even the enemies trusted once upon a time, can no longer gain the confidence of his closest relatives. Our Prophet heralded "those who protect the midst of their mouth and legs" with heaven by saying "Muslim is the one who is sure of his hand and tongue" (Vakkasoğlu, 2009).

Information on business ethics and the necessary characteristics of Muslim entrepreneurs are stated in verses in the Qur'an. Islam supports trading and entrepreneurship as it can be interpreted from the verses.

- "Allah hath permitted exchange, that is to say, trade and forbidden usury" (Qur'an, Baqarah, 275)

- "Eat not up your property among yourselves in vanities: But let there be amongst you traffic and trade by mutual good-will” (Qur'an, An-Nisáa, 29)

- "If any do seek for glory and power,- to Allah belong all glory and power. To Him mount up (all) Words of Purity: It is He Who exalts each Deed of Righteousness. Those that lay Plots of Evil,- for them is a chastisement terrible; and the plotting of such will be void (of result)" (Qur'an, Fátir, 10)

In today's world, all communities can be engaged in mutual commercial interactions thanks to technology. Muslim entrepreneurs who implement the above mentioned commercial moral rules would be preferred as the individuals with whom people desire to do business in the whole world.

\section{Contribution of Islamic Entrepreneurial Culture}

First of all, it is necessary for every Muslim to learn enough knowledge to save him from the responsibility for earthly life and end of life. Because Muslims can get rid of the disasters of the world and afterlife thanks to theknowledge and find happiness in both lives. In this context, a Muslim entrepreneur must learn knowledge so that he could save himself from the responsibility of the marketplaces; there are a number of aspects that need to be owned by a Muslim merchant by the title of entrepreneur. These are courage, selfpossession, patience, and glorification. Besides, a Muslim entrepreneur is the person upon whom everyone relies (Özakyol, 1965: 74-80). In this context, a Muslim entrepreneur should be brave about starting a new business, should not exceed his authority in his activities, should be sober-minded, should learn knowledge and should be patient for the behaviors of the opposite person. He may not make a profit immediately; he should thank Allah by considering that he would make a profit in time.

It is emphasized that learning knowledge is very important for the Muslim community in the Qur'an. Learning knowledge will ensure that Muslims will be happy in both worlds by illuminating their way of life.

- "Say: "O ye My servants who believe! Fear your Lord, good is (the reward) for those who do good in this world. Those who patiently persevere will truly receive a reward without measure!" (Qur'an, Az-Zumar, 10)

- "O my People! if ye realize this not, ask of those who possess the Message" (Qur'an, An-Nahl, 43)

Islam always encourages individuals to learn knowledge, investigate and implement the useful information they have learned through knowledge in their life.

Islam accepts people's property as a principle. Islam only seeks for exertion on the basis of earnings and property which are acquired in accordance with the principles set forth and based on fair earning. This exertion can be physical or mental. Islam has forbidden usury because it seeks for exertion on the basis of earning. Because increasing the capital through lending money refers to obtaining a product without exertion. Islam does not regard the profit made by means of usury, gambling, fraudulence, black-marketeering and excessive earnings as legitimate (Kutup, 1995: 55).

According to themarket economy, the right of property means that people protect and sell their assets by their own will. The right of property gives people opportunity to purchase the goods and services they need from the market. People have to work continuously, produce and compete to acquire these assets. The size of the wealth of countries depends on the volume of trade. The volume of trade depends on the size and freedom of the market traded (Erdem, 2015: 17). The entrepreneur, the most important determinant of themarket economy, is a product of the socio-economic and cultural environment in which the individual life exists (Eyuboğlu, 2004:15).

According to the Islamic perspective, the key role of the entrepreneur is to recognize the production activity required by the society and to take risks to meet all needs. According to the Islamic entrepreneurial culture, theentrepreneur may also want to acquire wealth to contribute to the development of the society, meet the needs of the less privileged citizens living in the same society, and offer products and services in the country or around the world (Khan, 2014: 60-61). However, as it was stated by Türkmen (2007), the spread of 
degenerated cultural behaviors such as craftiness and hitting the jackpot is inevitable in societies without a strong entrepreneurial culture (cited by:Marangoz, 2016A: 35).

\subsection{Contribution of the Islamic Entrepreneurial Culture in Terms of Social Transformation}

Religion is not only a phenomenon remaining as a life, idea, and thinking; on the contrary, religion can also be observed as volitional behaviors in every period of history and in every society. Although the person who perceives the sense of religion is the individual himself in the first step, the announcement of this feeling through conveyance and consequently its expansion lead to the formation of a community by those who accept that conveyance. In religious communities that emerge in this way, it is seen that individuals who share the same religious feelings are deeply affected by each other with respect to religion and other social issues. This feeling of religion is associated with the phenomenon and situations faced by individuals in everyday life such as the family, profession, management, language and admiration of individuals; the feeling of religion creates various principles called the world perspective.In summary, the feeling of religion creates a different community by leading individuals to gain a different personality with a different inner life, and the world perspective of this feeling regulates the social life (Atay, 1995:3-4).

According to Fazlur Rahman who developed the society and human understanding which is called sociology of change, society has a structure which is in a continuous process of change. The sociology of change is a scientific discipline that examines the social change and tries to understand its objectives. The dimensions of social change are very large. There is a change not only in the fields of economy, social, daily life, technology, and science but also in individuals' mentality, ways of thinking and perspectives on life as a consequence of them (Rahman, 2010:18-19).

It has been argued that societies leading in technology and competition which have completed their development in terms of individualism and socialism have individualistic cultures; and in connection with this, individualism has a positive meaning for entrepreneurship. Because the behaviors such as atendency to independence and rationality commonly observed in these societies are expressed as entrepreneurial characteristics (İrmiş et al., 2010: 48).

Social change has driving forces. The Prophet focused on three important issues; the first one is oneness, the second one is the person's moral duties towards human self and society, and the third one is the belief of afterlife. According to Fazlur Rahman,the most important driving forces of social change are these three points. Therefore, today's Muslim societies can solve their problems by tending towards the Qur'an and acting in accordance with it. Islamic concepts should be developed and renewed in parallel with the social change (Rahman, 2010: 20-21).

\subsection{Contribution of the Islamic Entrepreneurial Culture in Terms of Economic Empowerment}

One of the most important factors in the development of the countries and communities is the presence of individuals who have the spirit of entrepreneurship and are capable of bringing these features to theforefront in practice (Çonkar and İlter, 2005: 203). Entrepreneurs are the main actors of the economy in which they exist in the use of available resources by their decisions and practices they undertake. Entrepreneurs decide on behalf of consumers by determining the products they will produce and services. When they go into production, they will have made the allocation of resources in their own power by bringing together the capital, raw materials, natural resources and manpower within their knowledge and manners. In summary, the entrepreneur leads the supply and demand, makes an investment and looks for themarket. Economies based on market mechanism leave the entrepreneurship role to owners-managers of the default private businesses with which they operate by the motive of "making a profit" (Eyuboğlu, 2004: 15).

The duty of mankind is to improve the world beyond prayer in Islam. In the religious sense, the purpose of trading in Islam is to make the world better as in all human activities. For instance; if you cut the tree to produce a pencil which is the greatest invention of mankind, you must plant a new one instead of it and also leave space for the survival of animals (Alserhan, 2011: XI). In this context, Islam also leads individuals to entrepreneurship. The duty of "reconstruction of the world" ( Qur'an, Hüd, 61) attributed to mankind in Islam encourages individuals to work and entrepreneurship. In addition, it is possible to say that Islam offers different approaches according to the financial situations of people about entrepreneurship. Islam encourages both those with certain physical assets and those without them to entrepreneurship and even makes it mandatory. The Qur'an includes these expressions "Successful indeed are the Believers,- Those who humble themselves in their prayers; Who avoid vain talk; Who are active in given Zakat"(Al-Müminün, 1-4). According to this approach, a Muslim should not think that "I am not wealthy, I do not need to give alms"; on the contrary, should think that "I should work, make a profit and I can come to the level to give alms". A Muslim who thinks in this way accepts one of the factors encouraging him to be anentrepreneur as being helpful to others by giving alms (Eren, 2012:55-56). Islam prohibits usury and makes alms fardh. Usury is only making money from money without 
producing. The justification of the prohibition of usury is the prohibition of labor exploitation and unfair profits by encouraging labor and production (İslamoğlu, 2014: 161).

Islam directs individuals to work in society by encouraging entrepreneurship. In this way, the economic empowerment of all individuals in society is intended. Because being poor may drive individuals to bad thoughts and actions.

According to Tabbara, "poor people at a lower status in communities are the source of disturbance for those communities. Those who fall into the chain of poverty resort to doing many evils to supply essential needs for the maintenance of life. Because hunger leads people to commit all kinds of crimes. All kinds of ugly acts are also committed."(cited by: Aydın,2015: 2).

All over the world, the increased visibility of Muslim entrepreneurs blending religious principles and capitalist inspiration in an innovative and successful way, the increase in the numbers of Muslims, the connections between Muslims through values and lifestyle, the increasing social, economic and political power and influence of new Islamic social movements and the formalization of global, political, economic and international relations by the September 9 attacks have increased the interest in Muslims in terms of consumption and markets (Sand1kc1 and Rice, 2011:1).

There are material and cultural conditions necessary for Islamic countries to increase the economic growth and welfare level. However, the lack of solidarity and cooperation among Islamic countries makes it difficult for these countries to use their potential. Islamic World has established the Islamic Development Organisation (IDO) consisting of the countries the majority of thepopulation of which are Muslims. The main purpose of the organization is the development of political, economic, cultural, scientific and social solidarity and cooperation among member countries. Significant steps have been taken in a short time by gaining priority of the motives of cooperation for economic purposes and taking action together. However, these actions have been limited in terms of concrete results within a period of over 30 years (Arslan, 2014:179). It is an unavoidable fact that Muslim entrepreneurship will be facilitated due to the cooperation of Islamic countries. Thus, Muslim countries may have the chance to stand on their own legs by breaking the chain of poverty.

\section{Conclusion}

A Muslim scholar should base social change on Islamic foundation by investigating its content and finding out its driving forces so that Muslim societies can reach the development and welfare level they desire. The situation of Islamic countries which are colonized, have increased external debts and where the dominance of ignorance is permitted does not match up with Islam. The general Islamic principles extracted from the Qur'an and Hadith cannot be renewed by social change and hence never undergo a change (Rahman, 2010: 2021). In Islam, the Qur'an is a life guide which enables implementation by being interpreted in accordance with the requirements of the age in all periods. The important thing is to be able to read and live through the Qur'an. Organization of the Islamic Cooperation (OIC) 13th Islamic Summit was held in Istanbul between April 10-15, 2016. Recep Tayyip Erdoğan, President of Turkey, stated that only 20 of 56 member states paid their membership fees, other countries had difficulties in the payment. This situation indicates that the majority of Islamic countries have not been able to live through Islam yet from economical aspects.

Islamic culture has a feature to pave the way for the formation of appropriate social structure to raise honest entrepreneurial personality. Islamic culture supports the activities of the definitions corresponding to the concepts of trade or marketing, entrepreneur or merchant and can lead these activities by the rules it has set. Islam appeals to all mankind. It may be possible for the world communities which are seen to have become almost a single community due to technological advances in our day to implement the statement of Mustafa Kemal Atatürk, the founder of the Republic of Turkey, "peace at home, peace in the world" if they maintain their social and economic activities in accordance with the Islamic principles.

All world countries have been fighting against environmental pollution and many economic and political problems recently. Islamic culture has the ability to deal with all these problems experienced owing to the entrepreneurial culture perception in the Islamic marketing concept. The honest Muslim entrepreneurs who will maintain their commercial activities by considering the society, environment, nature and all living things and taking into account the exemplary personality of Prophet Muhammad (peace be upon him) have a key position in this regard.

\section{References}

[1] Akşit M.C., (2011), İslamda Ticaret Prensipleri, Gümüşev Yayıncılık, İstanbul.

[2] Alserhan B.A., (2011), The Principles of Islamic Marketing, Gower Publishing Ltd, England, http://www.amazon.com/dp/056608922X?, 13.04.2016, Copyrighted Material.

[3] Altunışık vd., (2016), Pazarlama İlkeleri ve Yönetimi, Beta Basım, Yayın No:3382, 2.Baskı, İstanbul.

[4] Arı E., (2015), "Sosyal Sorumluluk Sahibi Tüketim ve Etik: Türkiye Örneği”, Güncel Yaklaşımlar Işığında Etik, Editörler: R. Atabay ve N.Ö. İyigün, Beta Yayınları, İstanbul, 237-255.

[5] Arslan K., (2014), "İslâm Ülkeleri Arasında İşbirliğine Giden Yolda Yeni Arayışlar”, Uluslar arası Yönetim İktisat ve İşletme Dergisi, Cilt 10, Sayı 21, 179-198. 
[6] Aşkın A, vd., (2011), “Tarihsel Süreçte Girişimcilik Kavramı ve Gelişimi”, Girişimcilik ve Kalkınma Dergisi (6:2),s.56-61.

[7] Atay H. Vd., (1995), İslâm Gerçeği, Ankara Üniversitesi İlahiyat Fakültesi Yayınları NO:197, Ankara.

[8] Ateş S., (1997), İslam İlmihali, Yeni Ufuklar Neşriyat, 1.Cilt, İstanbul.

[9] Ay C. ve S. Nardalı, (2011), "Pazarlama Etiğì", İsletme Etiği, Editör: Z.Sabuncuoğlu, Beta Yayınları, İstanbul, 137-163.

[10] Aydın E., (2015), İslamiyetin Ekonomi Politiği, Literatür Yayınları, 10.Basım, İstanbul.

[11] Çevik E., (2006), "Girişimcilerin, Girişimcilik Tipleri İle Çalışma Amaçları Arasındaki İlişki, Marmara Üniversitesi Sosyal Bilimler Enstitüsü Yayınlanmamış Yüksek Lisans Tezi, İstanbul, s.42.

[12] Çonkar M.K. ve B.İlter, 2005, Ülke Kalkınmasında Grişimcilik ve Entelektüel Sermayboyutu, İktisat ve Girişimcilik Üniversitesi Türk Dünyası İsletme Fakültesi Ülkümüz Dergisi, Y11:2, Sayı:3, s.193-204.

[13] Durukan T., (2016), "Dünden Bugüne Girişimcilik ve 21. Yüzyılda Girişimciliğin Önemi”, Girişimcilik ve Kalkınma Dergisi, 1/2, Aralık, s.25-37.

[14] Erdem E., (2015), "Müslüman Bireyin İktisadi Davranış Hususiyetleri ve İslam Piyasa Geleneği”, İslam İktisadı ve Piyasa, İGİAD Yayınları:17, İstanbul, 11-38.

[15] Erdoğan R. T., (2016), http://www.aktifhaber.com/13-islam-zirvesi-toplantisinda-aidat-borcu-tartismasi-1331702h.htm

[16] Eren İ., (2012), "Girişimcilik ve Din: Temel Kaynakları Çerçevesinde İslâm’ın Girişimciliğe Bakışına Yönelik Bir Değerlendirme”, Girişimcilik ve Kalkınma Dergisi, (7:1)

[17] Erul B., (2015), "Hz. Peygamber ve Gençler”, Din ve Hayat, İstanbul Müftülüğü Dergisi, Sayı:25, 22-25.

[18] Eyuboğlu D., (2004), Girişimciliğin Geliştirilmesi, Milli Prodüktivite Merkezi Yayınları No:668, 2. Basım, Ankara.

[19] Güvenç B., (1984), İnsan ve Kültür, Remzi Kitabevi, İstanbul.

[20] Hofstede G., (2001), Culture's Consequences: Comparing Values, Behaviours, Institutions and Organizations Across Nations, Thousands Oaks, CA:Sage (co-published in the PRC as Vol. 10 in the Shanghai Foreign Language Education Press SFLEP Intercultural Communication Reference Series, 2008)

[21] İbn Hişâm, (2005), es-Sîretü’n-nebeviyye (nşr. Muhammed Alî el-Kutb-Muhammed ed-Dâlî Balta), I-IV, Beyrut, I, 105.

[22] İbn Sa'd, (1968), et-Tabakâtü'l-kübrâ (nşr. İhsan Abbas), I-IX, Beyrut, I,146.

[23] İrmiş vd., (2010), Girişimcilik Kültürü, Ekin Yayınları, Bursa.

[24] İslamoğlu M., (2014), Kur’an’a Göre İslâm Nedir, Düşün Yayıncılık, İstanbul.

[25] Kamacı F.Z., (2015), "Hz.Peygamberin Gençliği”, Din ve Hayat, İstanbul Müftülüğü Dergisi, Sayı:25, 16-21.

[26] Khan M.F., (2014), "İslam İktisadında Temel Kavramların ve Fikirlerin Yeniden Değerlendirilmesi: Kurumsal İçerik Açısından İslam İktisadının Kaynağı Ne Olmalıdır?’, İslam İktisadını Yeniden Düşünmek, İGİAD Yayınları:16, 2.Basım, İstanbul, 27-88.

[27] Kotler P., (2003), Marketing Management, 11.bask1, Pearson Education, Asia, India, s.8.

[28] Kur'an-1Kerim, http://quran.ksu.edu.sa/index.php?l=en\#aya=1_1\&m=hafs\&qaree=husary\&trans=en_sh

[29] Kutup s., (1995), İslam-Kapitalizm Çatışması, Çev:Y.N. Öztürk, Birleșik Yayıncılık:17, İstanbul.

[30] Makrîzî, (1999), İmtâ'u'l-esmâbimâli'r-Resûlmine'l-ebnâ'ive'l-ahvâl ve'l-hafedeve'l-Metâ (nşr. Muhammed Abdülhamîd enNemîsî), I-XV, Beyrut, I, 19.

[31] Marangoz M., (2016A), Girișimcilik, Genișletilmiș ve Güncellenmiș 3. Baskı, Beta Yayınları, İstanbul.

[32] Marangoz M., (2016B), Girişimcilikte Güncel Konular ve Uygulamalar, 1. Baskı, Beta Yayınları, İstanbul.

[33] Özakyol S., (1965), Cemiyetin Refahı İslâmda Ticaret, Ziraat ve Sınaat, Bizimyol Matbaası, İzmit.

[34] Raelin A.J., (1999), Kültürlerin Çatışması (Yönetenler-Yönetilenler), (Çev. Kamuran Kuncay, İstanbul, Türkiye İş Bankası Kültür Yayınları, Genel Yayın: 412, 13.

[35] Rahman F., (2010), İslam ve Çağdaşlık Fikrî Bir Geleneğin Değiş̧imi, Çev: A.Açıkgenç ve M.H. Kırbaşoğlu, Ankara Okulu Yayınları, Ankara.

[36] Rodinson M., (1976), İslam ve Kapitalizm, Hürriyet Yayınları, İstanbul.

[37] Sandıkcı Ö. Ve G. Rice, "Islamic marketing: an introduction and overview", Handbook of Islamic Marketing, Ed: Ö. Sandıkcı and G.Rice, EBSCO Publishing:eBook Collection(EBSCOhost), printed on 1/12/2016 via Afyon Kocatepe University.

[38] Scarborough N.M., (2014), Girişimciliğin ve Küçük İşletme Yönetiminin Temelleri, Çev: G.Sart, Yedinci Basımdan Çeviri, Nobel Yayınlar1,Ankara.

[39] Simșek O., (2013), Türk Girișimciliğinin Sosyolojisi, Otorite Yayınları, Ankara.

[40] Şişman M., (2011), Örgütler ve Kültürler, Pegem Akademi Yayınları, 3. Baskı, Ankara.

[41] Tylor E.B., (1971), On The Science of Culture, Marcello, Truzz (ed.),Sociology-The Classic Statements, New York, Rondom House, Inc.

[42] Tabbara, Prof. Afif Abdülfettah, (1981), İlmin Işı̆̆ında İslamiyet, Kalem Yayınları, İstanbul.

[43] Türkmen A., (2007), “Girişimcilik ve Girişimcilik Kültürü”, Selçuk Üniversitesi Sosyal Bilimler Enstitüsü, Yayınlanmamış Yüksek Lisans Tezi, Konya, s.54.

[44] Vakkasoğlu V., (2009), “Gerçek Müslüman Güvenilir Adamdır”, Sayı:103, Temmuz, http://www.gulistandergisi.com/dergi_oku.php?id=662. 